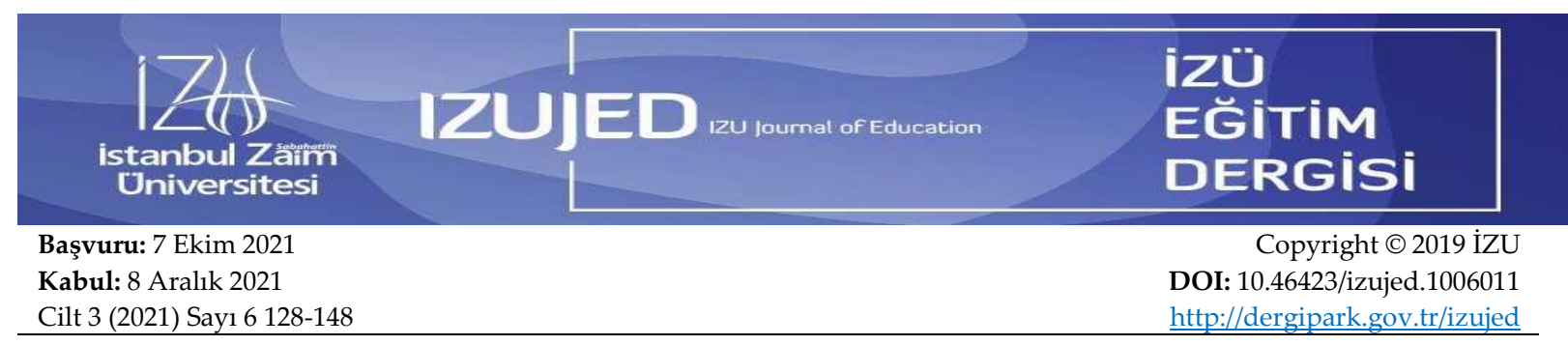

\title{
Yüz Yüze ve Online Eğitim Gören Yabancıların Türkçe Öğrenme Düzeylerini Etkileyen Faktörlerin İncelenmesi: Ankara Üniversitesi TÖMER Örneği*
}

Nermin Betül TANMANa

\author{
Mustafa ÖZGENEL ${ }^{b}$
}

\begin{abstract}
Öz
Günümüzde hayatımızın birçok alanında yüz yüze ve online eğitim kavramları giderek önem kazanan kavramlar olarak karşımıza çıkmaktadır. Bu kapsamda bu çalışmanın amacı, yüz yüze ve online eğitim gören yabancıların Türkçe öğrenme düzeylerini etkileyen faktörleri incelemektir. Çalışma, ilişkisel tarama modeline göre tasarlanmış ve çalışamaya Ankara Üniversitesi TÖMER'de yüz yüze ve online Türkçe öğrenim gören 360 yabancı öğrenici katılmıştır. Yabancı öğrencilerin Türkçe öğrenme başarılarını ölçmek için Ankara Üniversite'si TÖMER'in İstanbul, Kadıköy şubesinde 2019 ve 2020 yıllarında Türkçe öğrenmekte olan öğrencilerin performans çizelgeleri, sertifika sınav puanları ve devam durumları değerlendirilmiştir. Toplanan veriler $t$ testi, korelasyon ve regresyon analiz teknikleri yardımıyla çözümlenmiştir. Bulgulara göre yüz yüze eğitim alan yabancı öğrencilerin Türkçe öğrenme düzeylerini/ başarılarını sırasıyla en fazla derse devam durumlarının, dil gelişim hızlarının, ev ödevi yapma sıklıklarının ve derse katılımlarının olumlu yönde ve önemli ölçüde etki ettiği, online eğitim alan yabancı öğrencilerin ise Türkçe öğrenme düzeylerini/ başarılarını sırasıyla en fazla dil gelişim hızlarının, derse devam durumlarının ve derse katılım sıklıklarının olumlu yönde ve önemli ölçüde etki ettiği görülmüştür.
\end{abstract}

Anahtar Kelimeler: Yüz yüze Eğitim, Online Eğitim, Yabanc Dil Öğrenimi, Türkçe Öğretimi

\section{Examining the Factors Affecting the Turkish Learning Levels of Foreigners Studying Face- to-face and Online: Ankara University TÖMER Example}

\begin{abstract}
Today, in many areas of our lives, the concepts of face-to-face and online education are becoming increasingly important concepts. In this context, the aim of this study is to examine the factors affecting the Turkish learning levels of foreigners who receive face-to-face and online education. The study was designed according to the relational survey model and 360 foreign learners studying Turkish face-toface and online at Ankara University TÖMER participated in the study. In order to measure the success of foreign students in learning Turkish, the performance charts, certificate exam scores and attendance status of students learning Turkish in Istanbul, Kadıköy branch of Ankara University TÖMER in 2019 and 2020 were evaluated. The collected data were analyzed using t-test, correlation and regression analysis techniques. According to the findings, the Turkish language learning levels/success of foreign students receiving face-to-face education were found to have a positive and significant effect on their
\end{abstract}

\footnotetext{
a Sorumlu Yazar: Nermin Betül Tanman, Ankara Üniversitesi, İstanbul TÖMER / Turkey,

E-mail: betultanman@gmail.com

ORCID: 0000-0003-3179-8847

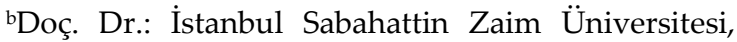
Eğitim Fakültesi, İstanbul, Turkey, E-mail: mustafa.ozgenel@izu.edu.tr

ORCID: 0000-0002-7276-4865
}

"Bu çalışma, Nermin Betül Tanman'ın, Doç. Dr. Mustafa Özgenel danışmanlığında yürütülen yüksek lisans tezinden üretilmiştir.

Atıf: Tanman, N. B. \& Özgenel, M. (2021). Yüz yüze ve online eğitim gören yabanclların Türkçe öğrenme düzeylerini etkileyen faktörlerin incelenmesi:

Ankara üniversitesi TÖMER örneği. İÜ Ĕ̆itim Dergisi, 3(6) 128-148. 
attendance, language development rate, homework frequency and class participation, respectively. It was seen that the rate of language development, attendance to class and frequency of class participation had a positive and significant effect, respectively.

Keywords: Face-to-Face Education, Online Education, Foreign Language Learning, Turkish Learning 


\section{Extended Abstract}

\section{Introduction}

Today, learning a foreign language is very important for both career and social life. Thanks to foreign language learning, we can find the opportunity to expand our horizons and thoughts by getting to know different cultures. In addition, with the increase in the relations of countries with each other, the desire to learn a foreign language has increased. Human is a social entity. Therefore, people want to meet different people, interact, learn about the cultures and cultural values of various countries. This desire has led to an increase in the desire to learn a foreign language in individuals, and it is seen that learning a foreign language has become a necessity for individuals (Demirel, 2010: 16; Köksal \& Varışoğlu, 2012). People need to learn a foreign language in almost every field they work. In addition, when the needs brought by life are considered, knowing a foreign language is no longer a privilege, it has become a necessity (Göçer, 2009).

When teaching Turkish to foreigners is so important, the concepts of face-to-face education and online education, which are among the education styles applied in teaching Turkish to foreigners, are also important concepts. Face to face education; It is all of the teaching activities carried out by the educators by the students coming to the formal education institutions at a predetermined time. In order for face-to-face education to take place, students and educators should be in the same environment at the same time, and students and educators should communicate one-to-one (MEB, 2019). Distance education, on the other hand, is all of the education and training activities in which educators and students are in different environments, communication is carried out with technological tools (İşman, 1998). In this context, in the research, "Does the level of Turkish learning of foreign students receiving faceto-face and online education significantly affect the student's desire to learn, class participation, frequency of homework, language development rate and attendance?" The answer to the research problem was sought. The aim of the research is to determine whether foreign students studying face-to-face and online at TÖMER have an effect on their level of learning Turkish, the learning style online and face-to-face education, the student's desire to learn, class participation, frequency of homework, language development speed and attendance.

\section{Method}

The research was carried out according to the relational survey model, one of the survey models, and 360 foreign students participated in the research. In the research, performance monitoring scale and certificate exam scale developed by TÖMER (2011) were applied to determine the Turkish learning levels of foreigners in face-to-face and online education. Necessary permissions were obtained from the Ethics Committee of Istanbul Sabahattin Zaim University and Ankara University TÖMER in the study. Data were analyzed by performing independent groups t-test, correlation and regression analysis.

\section{Findings and Discussion}

According to the research findings, it has been determined that the level of Turkish learning, the desire to learn Turkish, the level of participation in the lesson, the frequency of doing 
homework, the speed of language development and the attendance status of foreign students who study Turkish online and face to face are similar. It can be said that students have a choice in terms of education type (online, face-to-face) and that the education style is similar in terms of their Turkish learning levels provide a great advantage for students. The reason why the teaching style does not differ on student success can be shown as the correct way of teaching, taking into account the teaching styles (face-to-face and online).

According to the research findings, it has been determined that the level of Turkish learning, the desire to learn Turkish, the level of participation in the lesson, the frequency of doing homework, the speed of language development and the attendance status of foreign students who study Turkish online and face to face are similar. It can be said that students have a choice in terms of education type (online, face-to-face) and that the education style is similar in terms of their Turkish learning levels provide a great advantage for students.

It has been determined that the foreign students who receive face-to-face education have the most positive and significant effects on their Turkish learning level/success, respectively, their attendance, language development rate, frequency of doing homework and participation in the course. As the attendance, language development rate, frequency of homework and attendance of foreign students receiving face-to-face education increase, their Turkish learning levels/success also increase. In addition, it has been determined that the Turkish language learning levels/success of foreign students receiving online education are mostly positively and significantly affected by their language development rates, their attendance to classes and the frequency of their attendance. As the participation, language development rate and attendance of foreign students receiving online education increase, their Turkish learning levels/success also increase. 


\section{Giriş}

Günümüzde yabancı dil öğrenimi gerek kariyer gerekse sosyal hayat için oldukça önemlidir. Yabancı dil öğrenimi sayesinde farklı kültürler tanıyarak, ufkunuzu ve düşüncelerimizi genişletme imkânı bulabiliriz. Bunun yanı sıra ülkelerin birbiriyle olan ilişkilerinin artmasıyla birlikte, yabancı dil öğrenme isteğini arttırmıştır. İnsan sosyal bir varlıktır. Bu nedenle insanlar farklı insanlarla tanışmak, etkileşimde bulunmak, çeşitli ülkelerin kültürlerini ve kültürel değerlerini öğrenmek ister. Bu istek bireylerde yabancı dil öğrenme isteğinin arttırmasına sebep olmuştur, hatta bu durum yabancı dil öğrenmenin bireyler için bir ihtiyaç halini aldığ görülmektedir (Demirel, 2010: 16; Köksal ve Varışoğlu, 2012). İnsanlar çalıştıkları hemen hemen her alanda yabancı dil öğrenme ihtiyacı duyarlar. Bunun yanı sıra hayatın beraberinde getirdiği ihtiyaçlar düşünüldüğünde yabancı dil bilmek bir ayrıcalık olmaktan çıkmış, ihtiyaç haline gelmiştir (Göçer, 2009).

Türkçe tarihin ilk dönemlerinden beri gelişimini sürdüren, değişen ve zenginleşen bir dildir. Bu sebeple Türkçenin ana dil ve yabancı dil olarak öğretimi önemli bir yer tutmaktadır. Bu açıdan Türkçenin öğretimi konusu incelendiğinde birçok örnek karşımıza çıkmaktadır (Karakuş, 2006). Bu konuda bahsedilmesi gereken en önemli eserlerden biri Araplara Türkçeyi öğretmek amacıyla yazılmış ilk eser olan Divan-ü Lügat-it Türk'tür. Arapça - Türkçe bu sözlük sayesinde Türkçenin de Arapça kadar zengin bir dil olduğunun gösterilmesi amaçlanmıştır. Türkçenin öğretilmesiyle ilgili yazılmış ikinci eser ise Codeks Comanicus'tur. Codeks Comanicus yaklaşık olarak 1303-1362 yılları arasında, Latin alfabesiyle, Kıpçak Türkçesini öğretmek amacıyla yazılmıştır (Karakuş, 2006). Tüm bunlardan anlaşılacağı üzere geçmişten günümüze Türkçenin öğrenimi ve öğretimi önemli bir yer tutmaktadır.

Türkiye'nin giderek önem kazandığı günümüzde, Türkçe öğrenimi de önem kazanmaktadır. $\mathrm{Bu}$ doğrultuda Türkçe öğretimi amacıyla yurt dişında sayıları hızla artan Yunus Emre Enstitüsüne bağlı Türkçe öğretim merkezleri (YETEM), yurt içinde ise üniversitelere bağlı Türkçe öğretim merkezleri (TÖMER) ve dil öğretim merkezleri (DİLMER) bulunmaktadır. Bu durum bize eski çağlardan beri yabancılara Türkçe öğretiminin çok önemli olduğunu ve geçmişten günümüze kadar bu durumun devam ettiğini göstermektedir. Türkçenin her geçen gün daha popüler bir dil haline gelmesi hem Türkiye'de yaşamakta olan yabancılar hem de Türkiye dışında yaşayan ve Türkçe öğrenmek isteyen yabancılar için önemli bir hale gelmiştir. Bu nedenle Türkçenin yabancılara öğretimi konusu dikkat edilmesi, üzerinde düşünülmesi ve çalışılması gereken bir konudur (Göçer, 2009). Yabancılara Türkçe öğretiminin bu kadar önemli olduğu günümüzde yabancılara Türkçe öğretiminde uygulanan eğitim stillerinden olan yüz yüze eğitim ve online eğitim kavramları da önemli bir kavram olarak karşımıza çıkmaktadır.

Yüz yüze eğitim; öğrencilerin daha önce belirlenmiş bir zamanda örgün öğretim kurumlarına gelerek, eğitimciler tarafından yapılan öğretim etkinliklerinin tamamıdır. Yüz yüze eğitimin gerçekleşebilmesi için öğrencilerin ve eğiticilerin aynı anda aynı ortamda bulunması, öğrenciler ve eğiticiler birebir iletişim sağlamalıdır (MEB, 2019). Bunlar göz önüne alındığında bu eğitim şekli özellikle uygulamalı eğitimlerde oldukça elverişlidir. Beceri ve tutuma yönelik davranışların ortaya çıkmasında ve gelişmesinde de oldukça etkili bir öğretim tekniğidir. Ayrıca eğiticiler ve öğrenciler aynı zamanda aynı mekânda bulunmaları sosyalleşme imkanlarını da kolaylaştırmaktadır. Geçmişte sadece yüz yüze eğitimle sınırlanmış olan eğitim, bilişim teknolojilerindeki gelişmelerle birlikte web ortamına da taşınmıştır (Demir ve 
Gözüm, 2011). Bu doğrultuda öğrenme hedeflerine uygun metot ve teknoloji kullanıldığında; öğrencilerin birbirleriyle etkileşim içerisinde olması sağlandığında ve öğrenciye zamanında gerekli dönütler verildiğinde uzaktan eğitiminde yüz yüze eğitim kadar etkili olabileceği ileri sürülmektedir (Karataş, 2003).

Uzaktan eğitim, eğiticilerin ve öğrencilerin farklı ortamlarda bulunduğu, iletişimin teknolojik araçlar ile gerçekleştirildiği, eğitim ve öğretim etkinliklerinin tamamıdır (İşman, 1998). Uzaktan eğitim, öğretmen ve öğrencilerin farklı mekânlarda bulunduğu, öğrenme faaliyetlerinin basılı, elektronik, hareketli ve sesli materyallerle yapıldığı, çevrimiçi (online) veya çevrimdışı, eş zamanlı veya eş zamansız olarak gerçekleştirilebilen ve yüz yüze öğretim faaliyetleri ile desteklenmekte olan öğretim biçimidir (Gülüşen, 2011). Uzaktan eğitim oldukça tercih edilen bir yöntemdir. Çünkü gerek öğreticilere ve yöneticilere gerekse öğrencilere büyük avantajlar sunmaktadır. Bu avantajlar (Yazıcı, 2004; Eisinger, 2009'dan Akt. Balta, 2014):

- Eğitim hizmetleri daha geniş kitlelere götürülebilmektedir.

- Eğitimde imkân ve fırsat eşitliği sağlamaktadır.

- Öğrenilenlerin akılda kalma oranı ve motivasyonda yükselme sağlanmaktadır.

- Farklı mekanlarda bulunan uzmanlardan faydalanılabilmektedir.

- Farklı bireyler için farklı hız ve yöntemlerle öğrenme imkânı sunmaktadır.

- Bu yöntemle yaşam boyu öğrenme olanağı sunulmaktadır.

- Gereken bilgilere istenilen zamanda ulaşım sağlanmaktadır.

- Öğrencilerin öğrenme hızlarına göre planlama yapılabilir.

- Bazı kişilik özelliklerine sahip öğrencilerin (konuşma güçlüğü, utangaç olma vb.) verimliliğinin artması sağlanmaktadır.

- Öğrenim maliyetleri diğer yöntem ve tekniklere göre oldukça düşüktür.

Bilgisayar ve internet teknolojisinin her geçen gün geliştiği ve bugün geldiği noktada birçok eğitim kurumu uzaktan eğitime geçiş yapmıştır (Tosun, 2007). Uzaktan eğitimde web teknolojilerinin kullanılmasıyla oluşturulan eğitim yöntemi ise "online eğitim" kavramı olarak adlandırılmaktadır. Online eğitim Horton (2000) tarafından "amaçlı ya da amaçsız, insanı herhangi bir alanda eğitebilmek amacıyla web teknolojilerinin kullanılması" olarak tanımlanmaktadır. Web teknolojileri ile oluşturulan sanal öğrenme ortamlarında öğretmen ve öğrenciler, metin, grafik, veri ve formül gibi öğeleri paylaşabilirler ( $\mathrm{O}^{\prime} \mathrm{Neil}$, Fischer, Cherly ve Newbold, 2009). Maliyet açısından bakıldığında online eğitimin maliyetinin geleneksel örgün eğitim maliyetlerine göre neredeyse yarı yarıya daha düşük olduğu görülmektedir. Bunun yanında online eğitimin etkileşimli eğitim özelliği ve güncel içeriklere ulaşımın kolay olması da göz ardı edilmemelidir (Docent Inc, 2002' den Akt. Al ve Madran, 2004). Bunun yanı sira online eğitimde coğrafi olarak ya da geçici bir süre için gitmek zorunda olan öğrencilere etkileşimde olma ve bilgi paylaşımı yapabilme, iş birlikli çalışmalarda görev alabilme imkânı sağlanmaktadır. Böylece coğrafi sınırlar ortadan kalkmakta ve öğrencilerin her konu için çok kültürlü bir bakış açısına sahip olmasını sağlamaktadır. Ayrıca öğretmenlerin ve öğrencilerin sınıftan bağımsız olması, bina ve personel ihtiyacının bulunmaması, eğitim-öğretim giderlerinin azalması açısından da birçok avantajı bulunmaktadır (Yeniad, 2006).

Başlangıçta uzaktan eğitim programları, geleneksel eğitim programlarını desteklemek amacıyla kullanılmıştır. Fakat uzaktan eğitim programlarının sağladığı avantajlar sebebiyle bu programlara talep artmıştır. Bunun yanında her geçen gün teknolojik gelişmelerin olması ve teknolojinin hayatı kolaylaştırması, eğitimde teknolojinin kullanılmasını sağlamıştır (Çallı, 
Bayram ve Karacadağ, 2002; Zırhlığlu, 2006). Literatürdeki araştırmalar genel olarak değerlendirildiğinde yüz yüze eğitimin online eğitime (Eroğlu, 2018; Eroğlu ve Kalayc1, 2020; Kaya, 2012), uzaktan eğitimin yüz yüze eğitime göre daha etkili olduğu belirlenmiştir (Çataloğlu, Erbay ve Kör, 2012; Kör, 2013). Yine yüz yüze ve online eğitim arasında anlamlı bir farklılık oluşmadığ 1 (Bahşi, 2019; Karataş, 2003), yaş, öğrenim durumu, cinsiyet, kayg1 ve motivasyon, öğrenim şekli, öğrencilerin derse karşı tutumu gibi pek çok değişkenin öğrencilerin akademik başarısını etkilediği tespit edilmiştir (Aslan ve Coskun, 2016; Bahşi, 2019; Kaya, 2012; Khomeniuk, 2020; Kör, 2013; Kurt, 2021).

Yabancıların Türkçe öğrenimi konusunda Büyükikiz ve Hasırcı (2013) yaptığı araştırmada dil öğretiminin sözlükler ve metin tercümeleri temelinden ziyade iletişime yönelik yapılmasının daha etkili olduğunu rapor etmiştir. Khomeniuk (2020) çalışmasında Türk Dili ve Edebiyatını öğrenen yabancı öğrencilerin genel problemlerinin Türk kültürüne ilişkin unsurların anlaşılamamasından kaynaklandığı tespit etmiştir. Şenyiğit ve Okur (2019) kelimelerin sadece sözlükbirim bazında değil, her sözlükbirimin farklı anlamları düzeyinde de dil seviyeleriyle ilişkilendirilmesinin Türkçe öğreniminde daha etkili olacağı sonucuna ulaşmıştır. Aslan ve Coşkun (2016) yaptıkları araştırmada sözcük öğretiminde oyun ve bulmaca gibi çeşitli aktivitelerin yapılmasının öğrencilerin ilgi ve motivasyonlarını arttırdığı ortaya çıkmıştır. Dündar'ın (2019) yaptığı araştırmada ise öğrencilerin \%94,44'ünden, internet tabanlı izle Öğren uygulamasının Türkçe öğrenmelerine katkı sağladığı tespit edilmiştir. İlgili literatür yüz yüze eğitim ve online eğitimin karşılaştırılması konusunda incelendiğinde ise Eroğlu ve Kalaycı' nın (2020) yaptığı araştırmada uzaktan eğitim uygulamalarının, yüz yüze eğitime göre daha çok avantajının olduğu sonucuna ulaşmıştır. Fakat uzaktan eğitim uygulamasının başarılı olabilmesi için en önemli şartın doğru bir şekilde planlanıp uygulanabilmesi olduğu ifade edilmiştir. Kör'ün (2013) yaptığı araştırmada ise Kırklareli Üniversitesinde uzaktan eğitim alan öğrencilerin, yüz yüze eğitim alan öğrencilere göre nispeten daha yüksek akademik başarı puanlarına sahip oldukları görülmektedir. Eroğlu (2018) uzaktan eğitim alan öğrencilerin derslerin işlenişi konusunda yeteri kadar verim sağlayamadığı ve bu derslere yalnızca sınavlarda başarılı olduklarını tespit etmiştir. Karataş (2003) örgün eğitim ile uzaktan eğitim öğrencileri arasında öğrenim durumları temel alındığında anlamlı bir farklılık oluşmadığını rapor etmiştir. Bahşi'nin (2019) araştırmasının da Karataş'ın (2003) araştırma sonucunu desteklediği görülmektedir. Çataloğlu, Erbay ve Kör'ün (2012) yaptığ1 araştırmada ise uzaktan eğitim öğrencilerinin başarıları örgün eğitimdeki öğrencilerle kıyaslandığında, uzaktan eğitim öğrencilerinin başarılarında daha belirgin bir artışın olduğu sonucuna ulaşılmıştır.

İlgili literatür incelendiğinde yabancıların Türkçe öğretiminde yüz yüze eğitim ile online eğitimi etkileyen faktörlerin karşılaştırılmasının incelenmediği görülmüştür. Hangi eğitim yönteminin yabancıların Türkçe öğrenmesi açısından daha kullanışlı ve verimli olduğu konusu da özellikle Yükseköğretim eğitimi bağlamında önem kazanmaktadır. Bu sebeple yabancıların Türkçe öğrenmesinde yüz yüze ve online eğitimi etkileyen faktörlerin incelenmesi gereken bir konudur. Türkçe öğretiminde yüz yüze eğitim ile online eğitimi etkileyen faktörlerin karşılaştırılması Yükseköğretim yönetimine katkı sağlayacağ1 söylenebilir. Araştırma sonucunda ortaya çıkacak bulgular yabancılara Türkçe öğretiminde görevli öğretmenler ve diğer eğitimcilere yabancllara Türkçe öğretilirken hangi eğitim yönteminin etkili olacağı ve nelere dikkat etmeleri gerektiği konusunda önemli ipuçları vereceği için önemli kabul edilebilir. Özellikle günümüzde yaşanan pandemi gibi küresel 
boyuttaki problemler online eğitime geçişi hızlandırmıştır. Bu anlamda da çalışmamızın önemli olduğu söylenebilir. Bunların yanında çalışmamız TÖMER, DİLMER gibi yabancılara Türkçe öğretimi yapan kurum ve kuruluşlar için yol gösterici olabilir. Bundan sonra bu alanlarda çalışma yapacak olan araştırmacılara yol gösterici bir model ve kaynak oluşturması çalışmanın önemli bir diğer özelliği olarak ifade edilebilir. Bu bağlamda araştırmada "Yüz yüze ve online eğitim gören yabancı öğrencilerin Türkçe öğrenme düzeylerini, öğrencinin öğrenme isteği, derse katılımı, ev ödevi yapma sıklığı, dil gelişim hızı ve devam durumu anlamlı bir şekilde etkilemekte midir?" araştırma probleminin cevabı aranmıştır. Araştırmanın amacı Ankara Üniversitesi TÖMER'de “Yüz yüze ve online eğitim gören yabancı öğrencilerin Türkçe öğrenme düzeylerini, öğrenim şeklinin (online ve yüz yüze eğitim), öğrencinin öğrenme isteğinin, derse katılımının, ev ödevi yapma sıklığının, dil gelişim hızının ve devam durumunun etkisi olup olmadığını belirlemektir. Belirlenen amaca uygun olarak aşağıdaki sorulara cevap aranmıştır.

- Yabancı öğrencilerin Türkçe öğrenme düzeyleri, öğrencinin öğrenme isteği, derse katılımı, ev ödevi yapma sıklığı, dil gelişim hızı ve devam durumu öğrenim şekline (online ve yüz yüze eğitim) göre anlamlı farklılık göstermekte midir?

- Yüz yüze ve online eğitim gören yabancı öğrencilerin Türkçe öğrenme düzeyleri ile öğrencinin öğrenme isteği, derse katılımı, ev ödevi yapma sıklığı, dil gelişim hızı ve devam durumu arasında anlamlı bir ilişki var mıdır?

- Yüz yüze ve online eğitim gören yabancı öğrencilerin öğrenme isteği, derse katılımı, ev ödevi yapma sıklığı, dil gelişim hızı ve devam durumlarının Türkçe öğrenme düzeylerini anlamlı bir şekilde yordamakta mıdır?

\section{Yöntem}

\section{Araştırma Modeli}

Yüz yüze ve online eğitim gören yabancı öğrencilerin Türkçe öğrenme düzeylerini, etkileyen faktörleri belirlemeyi amaçlayan bu araştırma, tarama modellerinden ilişkisel tarama modeline göre yürütülmüştür. Bu modele göre bağımsız değişkenin bağımlı değişkene olan etkisi araştırılır (Akgün, Büyüköztürk, Çakmak, Demirel ve Karadeniz, 2019: 25). Araştırmada öğrencilerin öğrenme isteği, derse katılımı, ev ödevi yapma sıklı̆̆ı, dil gelişim hızı ve devam durumu öğrenim şekli bağımsız değişken, öğrencilerin Türkçe öğrenme düzeyleri ise bağımlı değişkendir.

\section{Çalışma_Grubu}

Bu araştırmanın evrenini 2019-2020 yılında TÖMER'de öğrenim gören 4263 öğrenci oluşturmaktadır. Örneklem ise İstanbul Kadıköy TÖMER'de Türkçe öğrenmekte olan 352 öğrenciden oluşmaktadır. Araştırmanın örneklemi için ölçüt örnekleme yöntemi seçilmiştir. Belirli ölçüt ve nitelikleri karşılayan birimlerin örnekleme alınmasına Ölçüt Örnekleme denilmektedir (Akgün, Büyüköztürk, Çakmak, Demirel ve Karadeniz, 2019: 95). Örneklem büyüklügü belirlenirken $\% 95$ güven seviyesi ve $\% 5$ kabul edilebilir hata miktarı kriter olarak belirlenmiş ve en az 352 örneklem büyüklügüüün yeterli olacağı hesaplanmıştır. Bu araştırmada 360 yabancı öğrenci araştırmaya katılmış, örneklemin evreni temsil ettiğine karar verilmiştir. Yabancı öğrencilere ait demografik bilgiler Tablo 1'de verilmiştir. 
Tablo 1: Yabancı Öğrencilerin Türkçe Öğreniminde Dersin Öğrenim Şeklinin, Öğrencilerin Cinsiyet ve Yaşlarının Frekans ve Yüzde Değerleri

\begin{tabular}{|c|c|c|c|}
\hline & & Frekans & Yüzde \\
\hline \multirow{2}{*}{ Dersin Öğrenim Şekli } & Yüz Yüze & 180 & $\% 50$ \\
\hline & Online & 180 & $\% 50$ \\
\hline \multirow[t]{2}{*}{ Öğrencilerin Cinsiyeti } & Kadın & 289 & $\% 80,3$ \\
\hline & Erkek & 71 & $\% 19,7$ \\
\hline \multirow[t]{6}{*}{ Öğrencilerin Yaşı } & 16-20 Yaș Arası Öğrenciler & 38 & $\% 10,6$ \\
\hline & 21-25 Yaş Arası Öğrenciler & 168 & $\% 46,7$ \\
\hline & 26-30 Yaş Arası Öğrenciler & 56 & $\% 15,6$ \\
\hline & 31-35 Yaș Arası Öğrenciler & 35 & $\% 9,7$ \\
\hline & 36-40 Yaş Arası Öğrenciler & 33 & $\% 9,2$ \\
\hline & 40 Yaş Üstü Öğrenciler & 30 & $\% 8,3$ \\
\hline \multirow[t]{26}{*}{ Öğrencilerin Uyruğu } & Almanya & 20 & $\% 5,6$ \\
\hline & Amerika & 15 & $\% 4,2$ \\
\hline & Arabistan & 8 & $\% 2,1$ \\
\hline & Bahreyn & 5 & $\% 1,4$ \\
\hline & Belarus & 8 & $\% 2,2$ \\
\hline & Brezilya & 11 & $\% 3,1$ \\
\hline & Cezayir & 3 & $\% 0,8$ \\
\hline & Çin & 9 & $\% 2,5$ \\
\hline & Fas & 12 & $\% 3,3$ \\
\hline & Fransa & 5 & $\% 1,4$ \\
\hline & Güney Kore & 51 & $\% 14,2$ \\
\hline & İngiltere & 25 & $\% 7$ \\
\hline & İran & 41 & $\% 11,4$ \\
\hline & İtalya & 11 & $\% 3,1$ \\
\hline & Kanada & 11 & $\% 3,1$ \\
\hline & Kazakistan & 32 & $\% 8,9$ \\
\hline & Kırgizistan & 7 & $\% 1,9$ \\
\hline & Libya & 5 & $\% 1,4$ \\
\hline & Misir & 8 & $\% 2,2$ \\
\hline & Özbekistan & 4 & $\% 1,1$ \\
\hline & Polonya & 6 & $\% 1,7$ \\
\hline & Rusya & 25 & $\% 6,9$ \\
\hline & Suriye & 18 & $\% 5,0$ \\
\hline & Ukrayna & 14 & $\% 3,9$ \\
\hline & Ürdün & 6 & $\% 1,7$ \\
\hline & Toplam & 360 & $\% 100$ \\
\hline
\end{tabular}

\section{Veri Toplama_Araçları}

$\mathrm{Bu}$ araştırmada yüz yüze ve online eğitimde yabancıların Türkçe öğrenme düzeylerini belirlemek için TÖMER (2011) tarafından geliştirilen performans izleme ölçeği ve sertifika sınavı ölçeği uygulanmıştır.

Performans İzleme Ölçeği: Araştırmada yabancıların Türkçe öğrenme düzeylerini belirlemek için Ankara Üniversitesi TÖMER (2011) tarafından hazırlanan Kur Sonu Performans İzleme Ölçeği kullanılmıştır. Ölçeğin hedef kitlesini TÖMER'de Türkçe öğrenmekte olan öğrenciler 
oluşturmaktadır (TÖMER, 2020). Performans çizelgesi 5 durumu ölçmektedir. Bunlar: öğrencilerin öğrenme isteği, derse katılımı, ev ödevi yapma oranları, dil gelişim hızları ve devam durumlarıdır. Ölçekte iyi, orta ve zayıf olmak üzere 3'lü Likert kullanılmıştır.

Yabancıların Türkçe öğrenmesi için toplam 12 kur bulunmaktadır. Bu kurlar üç seviyeye ayrılır. Bunlar: Temel Türkçe, Orta Türkçe ve Yüksek Türkçedir. Temel, Orta ve Yüksek Türkçe sinıfları dört kurdan oluşmaktadır (TÖMER, 2020a). Kurlara devam eden ve temel ya orta kurları bitiren öğrencilerin tamamı TÖMER Müdürlüğü tarafından imzalanmış olan sertifikaları almaya hak kazanırlar. Yüksek kurlarda ise başarılı olan öğrenciler Ankara Üniversitesi Rektörlüğ̈̈ tarafından onaylanmış diploma almaya hak kazanmış olurlar. Öğrencilerin kur ve sınavlarda başarılı sayılabilmeleri için Avrupa Dil Portfolyosu'nda belirlenen Temel Beceri ve Kazanımları gerçekleştirmesi gerekir.

Kurların sınav yapılmayan ara kurlarında, öğrenciler kurs okutmanı tarafından kur süresince izlenir ve öğrencilerin temel beceri ve kazanımlarına göre performans değerlendirmesi yapılır. Okutman, öğrenciyi 5 temel dil becerisindeki başarılarını takip eder ve değerlendirir. Bunun sonucunda okutman tarafından doldurulan performans değerlendirmesi çizelgesi ile öğrencinin bir üst kura geçmesine veya öğrencinin başarısız olması durumunda aynı kuru tekrar etmesine karar verilebilir (TÖMER, 2020b). Kurlarda her öğrencinin derslere en az 7/8 oranında devam etmesi gerekmektedir. Mazeret bildirmeksizin devamsızlık oranını aşan öğrencilerin kur tekrarı yapmaları gerekir. Okutman gözlemleri sonucunda performans değerlendirme çizelgesini doldurur. Bu değerlendirme sonucunda okutman öğrencinin bir sonraki kura devam etmesine ya da kuru tekrar etmesine karar verebilir (TÖMER, 2020b).

Sertifika Sınavı Ölçeği: Araştırmada sertifikalı kurlarda yabancıların Türkçe öğrenme düzeylerini belirlemek için ise Ankara Üniversitesi TÖMER (2011) tarafından hazırlanan Sertifika Sınavı Ölçeği kullanılmıştır. Ölçeğin hedef kitlesini TÖMER'de Türkçe öğrenmekte olan öğrenciler oluşturmaktadır. Sertifika Sınavları 4 temel beceriden oluşmaktadır. Bunlar: Okuma, Dinleme, Konuşma ve Yazma becerileridir. Öğrencilerin sertifika sınavında başarılı olabilmeleri için her temel beceriden en az 15 puan almaları gerekir. Her bir temel beceri için en çok alabilecekleri toplam puan 25 puandır. Sertifika Sınavının ise alınabilecek en yüksek toplam puan 100 puandır. Okuma, Dinleme ve Yazma sınavları bir sınavdan, Konuşma sınavı ise 2 sınavdan oluşur. Bu sınavlar Sözlü Anlatım ve Karşılıklı Konuşma sınavıdır. Öğrencilerin konuşma sınavında başarılı olabilmeleri için Sözlü Anlatım sınavından en az 6, Karşılıklı Konuşma sınavından ise en az 9 puan almaları gerekir. Öğrencilerin bu sinavlardan alabilecekleri en çok puan Sözlü Anlatım sınavında 10, Karşılıklı Konuşma sınavında ise 15 puandır (TÖMER, 2020b). Sertifika sınavlarında değerlendirme yapılırken her seviye için Avrupa Dil Portfolyosu'nda belirtilen Temel Beceri ve Kazanımlar göz önünde bulundurulur.

Sertifika sınavlarının okuma ve dinleme sınavları okuma ve okuduğunu anlamaya yönelik sorulardan oluşmaktadır. Sorular soru değerlerine göre puanlanır. Bu sınavlardan alınabilecek en yüksek puan 25 puandır. Yazma, sözlü anlatım ve karşılıklı konuşma sınavlarında ise puanlama okutman tarafından doldurulan ölçek sayesinde yapılır. Merkezde uygulanacak sınavların türü, içerikleri ve uygulanma süreçleri Yönetim Kurulu tarafından belirlenir (TÖMER, 2011).

Sözlü Anlatım Sınavı Değerlendirme ve Ölçütler: Sertifika sınavlarının Sözlü Anlatım sınavlarında kullanılan ölçek 5 alt boyuttan oluşmaktadır. Bunlar; Dil Bilgisi, Sözcük Bilgisi, Akıcılık, Tutarlılık ve Sesletim alt boyutlarından oluşmaktadır. Beş alt boyut kendi içinde 3 alt 
boyuta ayrılmıştır ve 3'lü Likert tipi kullanılmıştır. 0 puan en düşük puanı, 2 puan ise en yüksek puanı ifade etmektedir. Ölçekte alınabilecek toplam puan 10'dur.

Karşılıklı Konuşma Sınavı Değerlendirme ve Ölçütler: Karşılıklı Konuşma sınavlarında kullanılan ölçek 6 alt boyuttan oluşmaktadır. Bunlar; Dil Bilgisi, Sözcük Bilgisi, Akıcılık, Dinleme Becerisi, İletişim Kurma ve Diyaloğu Sürdürme alt boyutlarıdır. Bu alt boyutlar kendi içinde alt boyutlara ayrılmaktadır. Bu alt boyutlardan Dil Bilgisi, Dinleme Becerisi ve İletişim Kurma alt boyutları 3 alt boyuttan oluşmaktadır ve 3'lü Likert tipi kullanılmıştır. Burada 0 puan en düşük puanı, 2 puan ise en yüksek puanı ifade etmektedir. Sözcük Bilgisi, Akıcılık ve Diyaloğu Sürdürme alt boyutları ise 4 alt boyuttan oluşmaktadır ve 4 'lü Likert tipi kullanılmıştır. Burada ise 0 puan en düşük puanı, 3 puan ise en yüksek puanı ifade etmektedir. Ölçekten alınabilecek toplam puan 15'tir.

Yazılı Anlatım Sınavı Değerlendirme ve Ölçütler: Yazılı Anlatım sınavlarında kullanılan ölçek ise 5 alt boyuttan oluşmaktadır. Bunlar; Dil Bilgisi, Sözcük Bilgisi, Tutarlılık, Uzunluk ve Yazım ve Noktalama İşaretlerim alt boyutlarıdır. Bu alt boyutlar kendi içinde 3 alt boyuttan oluşmaktadır ve 3'lü Likert tipi kullanılmıştır. Burada 0 puan en düşük puanı, 5 puan ise en yüksek puanı ifade etmektedir. Bu ölçekten alınabilecek en yüksek toplam puan 25'tir.

\section{Verilerin Toplanması}

Araştırmada İstanbul Sabahattin Zaim Üniversitesi Etik Kurulundan ve Ankara Üniversitesi TÖMER'den gerekli izinler alınmıştır. Bu doğrultuda ölçek sonuçları Ankara Üniversitesi TÖMER'den istenmiş ve araştırma sonuçlarının gizlilik ilkesi doğrultusunda kimseyle paylaşılmayacağı açıklanarak güven sağlanmıştır.

\section{Verilerin Analizi}

Araştırmada, Yabancıların Türkçe öğrenme düzeylerini belirlemek için aritmetik ortalama ve standart sapma değerleri hesaplanmıştır. Yüz yüze ve online eğitim ile yabancıların Türkçe öğrenme düzeylerinin diğer değişkenler arasında farklılaşmaya sebep olup olmadığını analiz etmek için $\mathrm{t}$ testi; Yüz yüze ve online eğitim ile Yabancıların Türkçe öğrenme düzeyleri arasındaki ilişkiyi belirlemek için korelasyon; Yüz yüze ve online eğitim ile yabancıların Türkçe öğrenme düzeylerinin birbiri üzerindeki etkisini ölçmek için Regresyon analizi kullanılmıştır.

\section{Bulgular}

Yabanc1 öğrencilerin Türkçe öğrenme düzeylerinin öğrenim şekline göre karşılaştırmak amacıyla yapılan bağımsız gruplar $\mathrm{t}$ testi sonucu Tablo 3.1'de verilmiştir.

Tablo 3.1. Yabancı Öğrencilerin Türkçe Öğrenme Düzeylerinin Öğrenim Şekline Göre Karşılaştırılması

\begin{tabular}{llcccccc}
\hline Değişkenler & Gruplar & $\mathrm{N}$ & $\mathrm{M}$ & $\mathrm{SD}$ & $\mathrm{t}$ & $\mathrm{df}$ & $\mathrm{p}$ \\
\hline \multirow{2}{*}{ Başarı puanları } & Yüz Yüze & 180 & 78,861 & 6,622 & \multirow{2}{*}{738} & \multirow{2}{*}{358} & \multirow{2}{*}{461} \\
\cline { 2 - 5 } & Online & 180 & 78,370 & 5,965 & & & \\
\hline
\end{tabular}


Tablo 4.1'e göre yabancı öğrencilerin Türkçe öğrenme düzeylerinin öğrenim şekline göre anlamlı farklılık göstermediği belirlenmiştir ( $p>$.05). Başka bir ifadeyle online ve yüz yüze Türkçe eğitim gören yabancı öğrencilerin Türkçe öğrenme düzeyleri benzerdir.

Yabancı öğrencilerin Türkçe öğrenme isteklerinin öğrenim şekline göre karşılaştırmak amacıyla yapılan bağımsız gruplar $t$ testi sonucu Tablo 3.2' de verilmiştir.

Tablo 3.2. Yabancı Öğrencilerin Türkçe Öğrenme İsteklerinin Öğrenim Şekline Göre Karşılaştırılması

\begin{tabular}{llllllll}
\hline Değişkenler & Gruplar & $\mathrm{N}$ & $\mathrm{M}$ & $\mathrm{SD}$ & $\mathrm{t}$ & $\mathrm{df}$ & $\mathrm{p}$ \\
\hline \multirow{2}{*}{ Öğrenme İsteği } & Yüz Yüze & 180 & 2,775 &, 335 & \multirow{2}{*}{229} & \multirow{2}{*}{358} & \multirow{2}{*}{, 819} \\
\cline { 2 - 5 } & Online & 180 & 2,766 &, 356 & & & \\
\hline
\end{tabular}

Tablo 3.2'ye göre yabancı öğrencilerin Türkçe öğrenme isteklerinin öğrenim şekline göre anlamlı farklılık göstermediği belirlenmiştir ( $p>.05$ ). Başka bir ifadeyle online ve yüz yüze Türkçe eğitim gören yabancı öğrencilerin Türkçe öğrenme istekleri benzer düzeydedir.

Yabancı öğrencilerin derse katılımlarının öğrenim şekline göre karşılaştırmak amacıyla yapılan bağımsız gruplar $\mathrm{t}$ testi sonucu Tablo 3.3'te verilmiştir.

Tablo 3.3. Yabancı Öğrencilerin Derse Katılımlarının Öğrenim Şekline Göre Karşılaştırılması

\begin{tabular}{lllllllll}
\hline Değişkenler & Gruplar & $\mathrm{N}$ & $\mathrm{M}$ & $\mathrm{SD}$ & $\mathrm{t}$ & $\mathrm{df}$ & $\mathrm{p}$ \\
\hline \multirow{2}{*}{ Derse katılım } & Yüz Yüze & 180 & 2,730 &, 359 & \multirow{2}{*}{, 578} & \multirow{2}{*}{358} & \multirow{2}{*}{, 564} \\
\cline { 2 - 6 } & Online & 180 & 2,708 &, 369 & & & & \\
\hline
\end{tabular}

Tablo 3.3'e göre yabancı öğrencilerin derse katılım düzeylerinin öğrenim şekline göre anlamlı farklılık göstermediği belirlenmiştir ( $p>05$ ). Başka bir ifadeyle online ve yüz yüze Türkçe eğitim gören yabancı öğrencilerin derse katılım düzeylerinin benzer olduğu belirlenmiştir.

Yabancı öğrencilerin ev ödevi yapma durumlarının öğrenim şekline göre karşılaştırmak amacıyla yapılan bağımsız gruplar $\mathrm{t}$ testi sonucu Tablo $4.4^{\prime}$ te verilmiştir.

Tablo 3.4. Yabancı Öğrencilerin Ev Ödevi Yapma Durumlarının Öğrenim Şekline Göre Karşılaştırılması

\begin{tabular}{lllllccc}
\hline Değişkenler & Gruplar & $\mathrm{N}$ & $\mathrm{M}$ & $\mathrm{SD}$ & $\mathrm{t}$ & $\mathrm{df}$ & $\mathrm{p}$ \\
\hline \multirow{2}{*}{ Ev Ödevi } & Yüz Yüze & 180 & 2,716 &, 381 & \multirow{2}{*}{1,378} & \multirow{2}{*}{358} & \multirow{2}{*}{169} \\
\cline { 2 - 5 } & Online & 180 & 2,661 &, 383 & & & \\
\hline
\end{tabular}

Tablo 4.4'e göre yabancı öğrencilerin ev ödevi yapma durumlarının öğrenim şekline göre anlamlı farklılık göstermediği belirlenmiştir ( $p>.05$ ). Başka bir ifadeyle online ve yüz yüze Türkçe eğitim gören yabancı öğrencilerin ev ödevi yapma düzeylerinin benzer olduğu tespit edilmiştir.

Yabancı öğrencilerin dil gelişim hızlarının öğrenim şekline göre karşılaştırmak amacıyla yapılan bağımsız gruplar $\mathrm{t}$ testi sonucu Tablo $3.5^{\prime}$ te verilmiştir.

Tablo 3.5. Yabancı Öğrencilerin Dil Gelişim Hızlarının Öğrenim Şekline Göre Karşılaştırılması

\begin{tabular}{lllllccc}
\hline Değişkenler & Gruplar & $\mathrm{N}$ & $\mathrm{M}$ & $\mathrm{SD}$ & $\mathrm{t}$ & $\mathrm{df}$ & $\mathrm{p}$ \\
\hline \multirow{2}{*}{ Dil Gelişim Hızı } & Yüz Yüze & 180 & 2,622 &, 411 & \multirow{2}{*}{1,072} & \multirow{2}{*}{358} & \multirow{2}{*}{285} \\
\cline { 2 - 4 } & Online & 180 & 2,575 &, 424 & & & \\
\hline
\end{tabular}


Tablo 3.5'e göre yabancı öğrencilerin dil gelişim hızlarının öğrenim şekline göre anlamlı farklılık göstermediği belirlenmiştir ( $p>.05$ ). Başka bir ifadeyle online ve yüz yüze Türkçe eğitim gören yabancı öğrencilerin dil gelişim hızlarının benzer olduğu görülmüştür.

Yabancı öğrencilerin devam durumlarının öğrenim şekline göre karşılaştırmak amacıyla yapılan bağımsız gruplar $\mathrm{t}$ testi sonucu Tablo 3.6' da verilmiştir.

Tablo 3.6. Yabancı Öğrencilerin Devam Durumlarının Öğrenim Şekline Karşılaştırılması

\begin{tabular}{llcccccc}
\hline Değişkenler & Gruplar & $\mathrm{N}$ & $\mathrm{M}$ & $\mathrm{SD}$ & $\mathrm{t}$ & $\mathrm{df}$ & $\mathrm{p}$ \\
\hline \multirow{2}{*}{ Devam Durumu } & Yüz Yüze & 180 & 2,730 &, 359 & \multirow{2}{*}{, 743} & \multirow{2}{*}{358} & \multirow{2}{*}{458} \\
\cline { 2 - 4 } & Online & 180 & 2,702 &, 349 & & \\
\hline
\end{tabular}

Tablo 3.6'ya göre yabancı öğrencilerin devam durumlarının öğrenim şekline göre anlamlı farklılık göstermediği belirlenmiştir ( $p>.05)$. Başka bir ifadeyle online ve yüz yüze Türkçe eğitim gören yabancı öğrencilerin devam durumlarının benzer olduğu görülmüştür.

Yüz yüze eğitim gören yabancı öğrencilerin Türkçe öğrenme düzeyleri ile öğrencinin öğrenme isteği, derse katılımı, ev ödevi yapma sıklığı, dil gelişim hızı ve devam durumu arasındaki ilişkiyi belirlemek amacıyla yapılan korelasyon analizi sonuçları Tablo 3.7' de verilmiştir.

Tablo 3.7: Yüz Yüze Eğitim Gören Yabancı Öğrencilerin Türkçe Öğrenme Düzeyleri ile Öğrencilerin Öğrenme İsteği, Derse Katılımı, Ev Ödevi Yapma Sıklığı, Dil Gelişim Hızı ve Devam Durumu Arasındaki İlişskiyi Tespit Etmek İçin Yapılan Korelasyon Analizi

\begin{tabular}{|c|c|c|c|c|c|c|c|}
\hline & & 1 & 2 & 3 & 4 & 5 & 6 \\
\hline \multirow{3}{*}{ 1-Başarı puanları } & $\mathrm{r}$ & 1 & $630^{* *}$ & $666^{* *}$ & $678^{* *}$ & $619^{* *}$ & $615^{* *}$ \\
\hline & $\mathrm{p}$ & & ,000 & 000 & ,000 & ,000 & ,000 \\
\hline & $\mathrm{N}$ & 180 & 180 & 180 & 180 & 180 & 180 \\
\hline \multirow{3}{*}{ 2-Öğrenme isteği } & $\mathrm{r}$ & & 1 & $721^{* *}$ & $667^{* *+}$ &, $504^{* *}$ & $478^{* * *}$ \\
\hline & $\mathrm{p}$ & & & ,000 & ,000 & ,000 & ,000 \\
\hline & $\mathrm{N}$ & & 180 & 180 & 180 & 180 & 180 \\
\hline \multirow{3}{*}{ 3-Derse katılım } & $\mathrm{r}$ & & & 1 & ,682** &, $582^{* *}$ & $482^{* * *}$ \\
\hline & $\mathrm{p}$ & & & & ,000 & ,000 & ,000 \\
\hline & $\mathrm{N}$ & & & 180 & 180 & 180 & 180 \\
\hline \multirow{3}{*}{ 4-Ev ödevi } & $\mathrm{r}$ & & & & 1 & ,631* &, $509^{* *}$ \\
\hline & $\mathrm{p}$ & & & & & ,000 & ,000 \\
\hline & $\mathrm{N}$ & & & & 180 & 180 & 180 \\
\hline \multirow{3}{*}{ 5-Dil gelişim hızı } & $\mathrm{r}$ & & & & & 1 & $384^{* * *}$ \\
\hline & $\mathrm{p}$ & & & & & & ,000 \\
\hline & $\mathrm{N}$ & & & & & 180 & 180 \\
\hline \multirow{3}{*}{ 6-Devam durumu } & $\mathrm{r}$ & & & & & & 1 \\
\hline & $\mathrm{p}$ & & & & & & \\
\hline & $\mathrm{N}$ & & & & & & 180 \\
\hline
\end{tabular}

Tablo 3.7'ye göre yüz yüze eğitim gören yabancı öğrencilerin Türkçe öğrenme düzeyleri ile öğrencilerin öğrenme isteği $(\mathrm{r}=.630 ; \mathrm{p}<.01)$, derse katılımı $(\mathrm{r}=.666 ; \mathrm{p}<.01)$, ev ödevi yapma sıklığ $1(\mathrm{r}=.678 ; \mathrm{p}<.01)$, dil gelişim hızı $(\mathrm{r}=.619 ; \mathrm{p}<.01)$ ve devam durumu $(\mathrm{r}=.615 ; \mathrm{p}<.01)$ arasında pozitif yönde ve orta düzeyde anlamlı ilişki tespit edilmiştir. Başka bir ifadeyle yüz yüze eğitim gören yabancı öğrencilerin öğrenme istekleri, derse katılımları, ev ödevi yapma 
sıklıkları, dil gelişim hızları ve devam durumları arttıkça Türkçe öğrenme düzeyleri/başarıları da artmaktadır.

Online eğitim gören yabancı öğrencilerin Türkçe öğrenme düzeyleri ile öğrencinin öğrenme isteği, derse katılımı, ev ödevi yapma sıklığı, dil gelişim hızı ve devam durumu arasındaki ilişkiyi belirlemek amacıyla yapılan korelasyon analizi sonuçları Tablo 3.8' de verilmiştir.

Tablo 3.8: Online Eğitim Gören Yabancı Öğrencilerin Türkçe Öğrenme Düzeyleri ile Öğrencilerin Öğrenme İsteği, Derse Katılımı, Ev Ödevi Yapma Sıklığı, Dil Gelişim Hızı ve Devam Durumu Arasındaki İlişkiyi Tespit Etmek İçin Yapılan Korelasyon Analizi

\begin{tabular}{|c|c|c|c|c|c|c|c|}
\hline & & 1 & 2 & 3 & 4 & 5 & 6 \\
\hline \multirow{3}{*}{ 1-Başarı puanları } & $\mathrm{r}$ & 1 & $633^{* *+4}$ &, $701^{* *}$ & $675^{* *}$ &, $760^{* *}$ & ,619** \\
\hline & $\mathrm{p}$ & & ,000 & ,000 & ,000 & ,000 & ,000 \\
\hline & $\mathrm{N}$ & 180 & 180 & 180 & 180 & 180 & 180 \\
\hline \multirow{3}{*}{ 2-Öğrenme isteği } & $\mathrm{r}$ & & 1 & $807^{* *}$ & $727^{*+*}$ & ,625** &, $562^{* * *}$ \\
\hline & $\mathrm{p}$ & & & ,000 & ,000 & ,000 & ,000 \\
\hline & $\mathrm{N}$ & & 180 & 180 & 180 & 180 & 180 \\
\hline \multirow{3}{*}{ 3-Derse katılım } & $\mathrm{r}$ & & & 1 & ,738** & $684^{* *}$ &, $515^{* * *}$ \\
\hline & $\mathrm{p}$ & & & & ,000 & ,000 & ,000 \\
\hline & $\mathrm{N}$ & & & 180 & 180 & 180 & 180 \\
\hline \multirow{3}{*}{ 4-Ev ödevi } & $\mathrm{r}$ & & & & 1 &, $723^{* *}$ & $484^{* *}$ \\
\hline & $\mathrm{p}$ & & & & &, 000 & ,000 \\
\hline & $\mathrm{N}$ & & & & 180 & 180 & 180 \\
\hline \multirow{3}{*}{ 5-Dil gelişim hızı } & $\mathrm{r}$ & & & & & 1 & $462^{* *}$ \\
\hline & $\mathrm{p}$ & & & & & & ,000 \\
\hline & $\mathrm{N}$ & & & & & 180 & 180 \\
\hline \multirow{3}{*}{ 6-Devam durumu } & $\mathrm{r}$ & & & & & & 1 \\
\hline & $\mathrm{p}$ & & & & & & \\
\hline & $\mathrm{N}$ & & & & & & 180 \\
\hline
\end{tabular}

**. Correlation is significant at the 0.01 level (2-tailed).

Tablo 3.8'e göre online eğitim gören yabanc1 öğrencilerin Türkçe öğrenme düzeyleri ile öğrencilerin öğrenme isteği ( $\mathrm{r}=.633 ; \mathrm{p}<.01)$, derse katılımı $(\mathrm{r}=.701 ; \mathrm{p}<.01)$, ev ödevi yapma sıklığ $1(\mathrm{r}=.675 ; \mathrm{p}<.01)$, dil gelişim hızı $(\mathrm{r}=.760 ; \mathrm{p}<.01)$ ve devam durumu $(\mathrm{r}=.619 ; \mathrm{p}<.01)$ arasında pozitif yönde ve orta düzeyde anlamlı ilişki tespit edilmiştir. Başka bir ifadeyle online eğitim gören yabancı öğrencilerin öğrenme istekleri, derse katılımları, ev ödevi yapma sıklıkları, dil gelişim hızları ve devam durumları arttıkça Türkçe öğrenme düzeyleri/başarıları da artmaktadır.

Yüz yüze eğitim gören yabancı öğrencilerin öğrenme isteği, derse katılımı, ev ödevi yapma sıklığı, dil gelişim hızı ve devam durumlarının Türkçe öğrenme düzeylerine etkisini tespit etmek için yapılan çoklu regresyon analizi sonuçları Tablo 3.9' da verilmiştir.

Tablo 3.9: Yüz Yüze Eğitim Gören Yabancı Öğrencilerin Öğrenme İsteği, Derse Katılımı, Ev Ödevi Yapma Sıklığı, Dil Gelişim Hızı ve Devam Durumlarının Türkçe Öğrenme Düzeylerine Etkisini Tespit Etmek İçin Yapılan Çoklu Regresyon Analizi

\begin{tabular}{lllllll}
\hline Bağımsız Değişken & $\begin{array}{l}\text { Bağımlı } \\
\text { Değişken }\end{array}$ & $\mathbf{B}$ & Std. Hata & $\mathbf{( \beta )}$ & $\mathbf{t}$ & $\mathbf{p}$ \\
\hline Sabit & Türkçe & 30,294 & 2,868 & & 10,561 &, 000 \\
\cline { 3 - 7 } Ö̆ğrenme isteği & Öğrenme & 2,510 & 1,395 &, 127 & 1,799 &, $\mathbf{0 7 4}$ \\
\hline
\end{tabular}




\begin{tabular}{|c|c|c|c|c|c|c|}
\hline Derse katılım & \multirow{4}{*}{$\begin{array}{l}\text { Düzeyi/ } \\
\text { Başarısı }\end{array}$} & 3,328 & 1,358 & 181 & 2,451 & ,015 \\
\hline Ev ödevi yapma & & 3,158 & 1,263 & ,182 & 2,499 & ,013 \\
\hline Dil gelişim hızı & & 3,609 & ,981 & ,224 & 3,680 & ,000 \\
\hline Devam durumu & & 5,301 & 1,006 & 288 & 5,271 &, 000 \\
\hline
\end{tabular}

Tablo 3.9 incelendiğinde yüz yüze eğitim alan yabancı öğrencilerin derse katılımı ( $\beta=.181$; $\mathrm{p}<.05)$, ev ödevi yapma sıklığı $(\beta=.182 ; \mathrm{p}<.05)$, dil gelişim hızı $(\beta=.224 ; \mathrm{p}<.05)$ ve devam durumlarının $(\beta=.288 ; p<.05)$ Türkçe öğrenme düzeylerini anlamlı bir şekilde yordadığ görülürken, yüz yüze eğitim alan yabancı öğrencilerin öğrenme isteği ( $\beta=.127 ; p>.05)$ Türkçe öğrenme düzeylerini anlamlı bir şekilde yordamadığı görülmektedir. Yüz yüze eğitim alan yabancı öğrencilerin derse katılımı, ev ödevi yapma sıklığı, dil gelişim hızı ve devam durumlarının Türkçe öğrenme düzeylerindeki/başarılarındaki toplam varyansın \%64'ünü açıklamaktadır ( $\mathrm{R}=.800 ; \mathrm{R}^{2}=.640$; Düzeltilmiş $\left.\mathrm{R}^{2}=.629 ; \mathrm{F}=61.768 ; \mathrm{p}<.000\right)$. Başka bir ifadeyle yüz yüze eğitim alan yabancı öğrencilerin Türkçe öğrenme düzeylerini/ başarılarını sırasıyla en fazla derse devam durumlarının, dil gelişim hızlarının, ev ödevi yapma sıklıklarının ve derse katılımlarının olumlu yönde ve önemli ölçüde etkilediği belirlenmiştir. Yüz yüze eğitim alan yabancı öğrencilerin devam durumları, dil gelişim hızları, ev ödevi yapma sıklıkları ve derse devam durumları arttıkça Türkçe öğrenme düzeylerinin de/ başarılarının da arttı̆̆ söylenebilir.

Online eğitim gören yabancı öğrencilerin öğrenme isteği, derse katılımı, ev ödevi yapma sıklığı, dil gelişim hızı ve devam durumlarının Türkçe öğrenme düzeylerine etkisini tespit etmek için yapılan çoklu regresyon analizi sonuçları Tablo 3.9' da verilmiştir.

Tablo 3.10: Online Eğitim Gören Yabancı Öğrencilerin Öğrenme İsteği, Derse Katılımı, Ev Ödevi Yapma Sıklığı, Dil Gelişim Hızı ve Devam Durumlarının Türkçe Öğrenme Düzeylerine Etkisini Tespit Etmek İçin Yapılan Çoklu Regresyon Analizi

\begin{tabular}{|c|c|c|c|c|c|c|}
\hline Bağımsız Değişken & $\begin{array}{l}\text { Bağımlı } \\
\text { Değişken }\end{array}$ & B & Std. Hata & $(\beta)$ & $\mathbf{t}$ & $\mathrm{p}$ \\
\hline Sabit & \multirow{6}{*}{$\begin{array}{l}\text { Türkçe } \\
\text { Öğrenme } \\
\text { Düzeyi/ } \\
\text { Başarısı }\end{array}$} & 38,020 & 2,229 & & 17,060 &, 000 \\
\hline Öğrenme isteği & &,- 844 & 1,290 &,- 050 &,- 654 &, $\mathbf{5 1 4}$ \\
\hline Derse katılım & & 3,774 & 1,268 & ,234 & 2,976 & ,003 \\
\hline Ev ödevi yapma & & 1,280 & 1,119 & ,082 & 1,143 & 254 \\
\hline Dil gelişim hızı & & 6,198 & ,901 & ,441 & 6,883 &, 000 \\
\hline Devam durumu & & 4,846 & 875 & 284 & 5,538 &, 000 \\
\hline
\end{tabular}

Tablo 3.10 incelendiğinde online eğitim alan yabancı öğrencilerin derse katılımı $(\beta=.234$; $\mathrm{p}<.05)$, dil gelişim hızı $(\beta=.441 ; \mathrm{p}<.05)$ ve devam durumlarının $(\beta=.284 ; \mathrm{p}<.05)$ Türkçe öğrenme düzeylerini anlamlı bir şekilde yordadığ görülürken, online eğitim alan yabancı öğrencilerin öğrenme isteği ( $\beta=-.050 ; p>.05)$ ve ev ödevi yapma sıklığ ${ }_{1}(\beta=.082 ; p>.05)$, Türkçe öğrenme düzeylerini anlamlı bir şekilde yordamadığı görülmektedir. Online eğitim alan yabancı öğrencilerin derse katılımı, dil gelişim hızı ve derse devam durumlarının Türkçe öğrenme düzeylerindeki/başarılarındaki toplam varyansın yaklaşık \%70'ini açıklamaktadır $(\mathrm{R}=.836$; $\mathrm{R}^{2}=.698$; Düzeltilmiş $\mathrm{R}^{2}=.690 ; \mathrm{F}=80.598 ; \mathrm{p}<.000$ ). Başka bir ifadeyle online eğitim alan yabanc1 öğrencilerin Türkçe öğrenme düzeylerini/ başarılarını sırasıyla en fazla dil gelişim hızlarının, derse devam durumlarının ve derse katılım sıklıklarının olumlu yönde ve önemli ölçüde etkilediği belirlenmiştir. Online eğitim alan yabancı öğrencilerin derse katılımları, dil gelişim 
hızları ve derse devam durumları arttıkça Türkçe öğrenme düzeylerinin de/ başarılarının da arttığ söylenebilir.

\section{Tartışma, Sonuç ve Öneriler}

Araştırma bulgularına göre online ve yüz yüze Türkçe eğitim gören yabancı öğrencilerin Türkçe öğrenme düzeylerinin, Türkçe öğrenme isteklerinin, derse katılım düzeylerinin, ev ödevi yapma sıklıklarının, dil gelişim hızlarının ve devam durumlarının benzer olduğu tespit edilmiştir. Öğrencilerin eğitim şekli (online, yüz yüze) açısından bir seçeneğe sahip olması ve eğitim şeklinin Türkçe öğrenme düzeyleri açısından benzer olmasının öğrenciler açısından büyük bir avantaj sağladığı söylenebilir. Yani öğrenciler hangi eğitim şeklini seçerse seçsin benzer öğrenme düzeylerine sahip olacağı için kendilerine uygun olan öğrenim şeklini seçebilme şansına sahip olabilirler. Bu durumun öğrenciler açısından büyük bir kolaylık ve avantaj olduğu söylenebilir. Bunun yanı sıra benzer bir şekilde yüz yüze ya da online eğitimin öğrenci başarısı üzerinde anlamlı bir farklılık göstermediği görülmektedir. Spooner vd. (1999) geleneksel ve uzaktan eğitimin öğrencilerin akademik başarılarının ve motivasyonlarının öğretim şekline göre farklılık göstermediğini tespit etmişlerdir. Karataş'1n (2003) yüz yüze ve uzaktan eğitimde öğrenme deneyimlerinin eşitliği üzerine yaptığı araştırma sonucunda örgün eğitim ile uzaktan eğitim öğrencileri arasında öğrenim durumları temel alındığında anlamlı bir farklılık oluşmadığı sonucuna ulaşmak mümkündür. Summers vd. (2005) uzaktan eğitim öğrencilerinin akademik başarıları ile geleneksel eğitim öğrencileri arasında akademik başarıları arasında anlamlı bir farklılığın olmadığını rapor etmişlerdir. Ayrıca öğrencilerin ödev yapma oranlarının da benzer olduğu görülmüştür. Yine aynı şekilde Stack (2015) tarafından yapılan çalışmada da benzer bir sonuç tespit edilmiştir. Bunun yanı sıra araştırmada öğrencilerin derse katılım ve devam durumlarınında benzer olduğu görülmüştür. Bahşi'nin (2019) uzaktan ve örgün eğitim öğrencilerinin eğitsel düşünce ve uygulamaları üzerine yaptığı çalışmalar sonucunda da örgün öğretim ile uzaktan eğitim öğrencileri arasında öğrenim durumları temel alındığında anlamlı bir farklılık oluşmadığı görülmektedir. Tüm bunlar ışığında araştırmamızda öğretim şeklinin öğrenci başarısı üzerinde farklılık göstermemesinin sebebi olarak öğretim şekillerinin (yüz yüze ve online) dikkate alınarak öğretimin doğru bir şekilde yapılması gösterilebilir. Öğretim şekilleri bazında doğru bir metot uygulandığında her iki öğretim şeklinin de gereken başarıya ulaşabileceği söylenebilir. Yüz yüze eğitim uygulamalarında öğrencilerin yaparak ve yaşayarak öğrenmelerine imkan verilerek, derse karşı ilgi ve motivasyonları yüksek tutulduğunda kalıcı ve hızlı bir öğrenmenin gerçekleştiği görülmektedir (Demirel, 2004). Uzaktan eğitim de doğru şekilde planlandığında ve uygulandığında yüz yüze eğitim kadar etkili ve verimli olmaktadır. Uzaktan eğitimi etkili ve verimli bir şekilde kullanabilmek için öğrencilerin ilgi ve motivasyonlarının yüksek olması sağlanmalı ve gerekli dönütlerin zamanında verilmesi gerekmektedir (Karataş, 2003).

Yabancı öğrencilerin derse karşı olan istek ve tutumlarının Türkçe öğrenme düzeyleri açısından önemli olduğu düşünülmektedir. Araştırmada yüz yüze ve online eğitim almakta olan yabancı öğrencilerin derse karşı isteklerinin benzer olduğu görülmektedir. Yabancı dil öğrenimi günümüzde birçok sebepten dolayı önemli hale gelmiştir. İnsanlar çalıştıkları hemen hemen her alanda yabancı dil öğrenme ihtiyacı duymaktadırlar. Bunun yanı sıra günümüzdeki ihtiyaçlar düşünüldüğünde yabancı bir dil bilmek tüm bireylerde olması 
gereken bir özellik haline gelmiştir (Göçer, 2009). Bu nedenle öğrencilerin öğrenme isteklerinin benzer olmasının dil öğreniminin önemiyle ilgili olduğu düşünülebilir.

Yüz yüze ve online eğitim gören yabancı öğrencilerin öğrenme istekleri, derse katılımları, ev ödevi yapma sıklıkları, dil gelişim hızları ve devam durumları arttıkça Türkçe öğrenme düzeyleri/başarıları da artmaktadır. Bunun yanı sıra online ve yüz yüze Türkçe eğitim gören yabancı öğrencilerin öğrenme isteklerinin, derse katılımlarının, ev ödevi yapma sıklıklarının, dil gelişim hızlarının ve devam durumlarının düzeylerinin benzer olduğu belirlenmiştir. Çeşitli sebeplerle derse olan ilgisini kaybeden ve öğrenme isteği düşen yabancı öğrencilerin Türkçe öğrenme düzeyleri/başarıları düşerken, derse ilgisi yüksek olan ve bununla birlikte öğrenme isteği de yüksek olan yabancı öğrencilerin Türkçe öğrenme düzeylerinin/ başarılarının arttı̆̆ı söylenebilir. Öğrenci derste etkin bir rol oynar ve öğrencinin bilgiyi keşfetmesi sağlanırsa yapılan öğretim daha kalıcı olur ve öğrenme daha hızlı bir şekilde gerçekleşir (Demirel, 2004). Bu kapsamda çeşitli sebeplerle derse katılımı az olan yabancı öğrencilerin Türkçe öğrenme düzeylerinin/başarılarının düşük, derse katılımı yüksek olan yabancı öğrencilerin Türkçe öğrenme düzeylerinin/başarılarının yüksek olduğu söylenebilir. Bunun yanı sıra yabancılara Türkçe öğretiminde de dil gelişim hızı yüksek olan öğrencilerin Türkçe öğrenme düzeylerinin ve akademik başarılarının yüksek olduğu, dil gelişim hızı düşük olan öğrencilerin Türkçe öğrenme düzeylerinin ve akademik başarılarının düşük olduğu ifade edilebilir.

Yapılan birçok araştırmanın sonucunda ev ödevi yapma sıklığının dersin başarısını pozitif yönde etkilediği görülmüştür (Epstein, 1983; Snow vd., 1991). Derste öğrenilen yeni bir konunun ders sonrasında pekiştirilmesi ve akılda kalıcılığının artması için ödev önemli bir rol oynamaktadır (Küçükahmet, 2002). Yabancılara Türkçe öğretimi açısından düşünüldügünde de ödevin yabancı dil öğrenimini pekiştiren ve kolaylaştıran bir yöntem olduğunu söylemek mümkündür. Öğrenciler öğrendikleri yeni konular sonrasında ödev yaptıklarında, yeni öğrendikleri konunun akılda kalıcılığı artacağı için, dili öğrenmelerinin de kolaylaşacağ söylenebilir. Ödevin yanı sıra devam durumları da yabancı dil öğrenimi açısından büyük önem taşımaktadır. Dil öğrenimi devam gerektiren zor bir iştir. Bu sebeple sistemli ve planlı bir şekilde öğrenimin gerçekleşmesi gerekir (Demirel, 2010). Buradan hareketle yabancıların Türkçe öğrenimi açısından düşünüldüğünde öğrencilerinin derse devam etmediği durumlarda Türkçe öğrenme düzeylerinin ve akademik başarılarının düşük olduğu, derse devam eden öğrencilerin ise Türkçe öğrenme düzeylerinin ve akademik başarılarının daha yüksek olduğu çıkarımı yapılabilir.

Araştırma bulgularına göre yüz yüze eğitim alan yabancı öğrencilerin derse katılımı, ev ödevi yapma sıklığı, dil gelişim hızı ve devam durumlarının Türkçe öğrenme düzeylerini anlamlı bir şekilde yordadığı görülürken; yüz yüze eğitim alan yabancı öğrencilerin öğrenme isteğinin Türkçe öğrenme düzeylerini anlamlı bir şekilde yordamadığı görülmektedir. Yüz yüze eğitim alan yabancı öğrencilerin Türkçe öğrenme düzeylerini/ başarılarını sırasıyla en fazla derse devam durumlarının, dil gelişim hızlarının, ev ödevi yapma sıklıklarının ve derse katılımlarının olumlu yönde ve önemli ölçüde etkilediği belirlenmiştir. Başka bir ifadeyle yüz yüze eğitim alan yabancı öğrencilerin devam durumları, dil gelişim hızları, ev ödevi yapma sıklıkları ve derse devam durumları arttıkça Türkçe öğrenme düzeylerinin de/ başarılarının da arttığı görülmektedir. Online eğitim alan yabancı öğrencilerin ise derse katılımı, dil gelişim hızı ve devam durumlarının Türkçe öğrenme düzeylerini anlamlı bir şekilde yordadığı görülürken, online eğitim alan yabancı öğrencilerin öğrenme isteği ve ev ödevi yapma 
sıklığının Türkçe öğrenme düzeylerini anlamlı bir şekilde yordamadığı görülmektedir. Online eğitim alan yabancı öğrencilerin Türkçe öğrenme düzeylerini/ başarılarını sırasıyla en fazla dil gelişim hızlarının, derse devam durumlarının ve derse katılım sıklıklarının olumlu yönde ve önemli ölçüde etkilediği belirlenmiştir. Başka bir ifadeyle online eğitim alan yabanc1 öğrencilerin derse katılımları, dil gelişim hızları ve derse devam durumları arttıkça Türkçe öğrenme düzeylerinin de/ başarılarının da arttığı söylenebilir. Yüz yüze eğitim alan yabancı öğrencilerin derse katılımı, ev ödevi yapma sıklığı, dil gelişim hızı ve devam durumlarının Türkçe öğrenme düzeylerindeki/başarılarındaki toplam varyansın \%64'ünü açıklarken, online eğitim alan yabancı öğrencilerin derse katılımı, dil gelişim hızı ve derse devam durumlarının Türkçe öğrenme düzeylerindeki/başarılarındaki toplam varyansın yaklaşık \%70'ini açılamaktadır. Bu durum bize online eğitim alan yabancı öğrencilerin Türkçe öğrenme düzeylerinin, yüz yüze eğitim alan yabancı öğrencilerin Türkçe öğrenme düzeylerine göre daha fazla etkilendiğini göstermektedir.

Yabancılara Türkçe öğretiminde online eğitim alan yabancı öğrencilerin Türkçe öğrenme düzeylerinin, yüz yüze eğitim alan yabancı öğrencilerin Türkçe öğrenme düzeylerine göre daha fazla etkilendiği görülmektedir. Öğrenciler online eğitim uygulamalarında derse gitmek için yolda zaman kaybetmedikleri gibi yol masrafı ya da kişisel giderlere para harcamadıkları için online eğitim hem zaman hem de maliyet açısından çok daha avantajlıdır. Bu doğrultuda öğrenciler yüz yüze eğitimde hem zaman hem de maliyet açısından olumsuz fikirlere sahip olmaktadır. Bu durum derse olan motivasyonlarına ve akademik başarılarına da etki etmektedir (Höçük, 2011). Bu doğrultuda online eğitimin öğrencilerin daha az yorulmasına ve derse daha hızlı bir şekilde uyum sağlamasına yardımcı olduğu söylenebilir. Bu durumda online eğitim alan yabancı öğrencilerin Türkçe öğrenme düzeylerinin, yüz yüze eğitim alan yabancı öğrencilerin Türkçe öğrenme düzeylerine göre daha fazla etkilenmesine sebep olduğu düşünülebilir.

Yabancılara Türkçe öğretiminde yüz yüze eğitimde ev ödevi yapma sıklı̆̆ı Türkçe öğrenme düzeylerini yordarken, online eğitimde ev ödevi yapma sıklığı Türkçe öğrenme düzeylerini yordamadığı görülmektedir. Bu durumun sebebi olarak online eğitimde ve yüz yüze eğitimde öğrencilere aynı oranda ödevin verilmemesiyle ilgili olduğu düşünülebilir. Cooper, Lindsay, Nye ve Greathouse'nin (1998) yaptığı araştırmada ödev miktarının öğrenme düzeyleri üzerinde büyük rol oynadığı ve verilen ödev miktarının akademik başarıyı doğru orantılı olarak etkilediğini tespit etmiştir. Bu kapsamda yabancılara Türkçe öğretiminde yüz yüze eğitimde bir ders saati 50 dakika iken, online eğitimde bir ders saati 40 dakikan oluşmaktadır. Öğrencilere verilen her ödev bir sonraki ders gününde sinıfta kontrol edilmektedir. Bu durumun öğrencilere yüz yüze eğitimde daha çok ödev verilebilirken, online eğitimde nispeten daha az ödev verilmesine sebep olduğu düşünülebilir. Bu durumun yabancılara Türkçe öğretiminde yüz yüze eğitimde ev ödevi yapma sıklığının Türkçe öğrenme düzeylerini yordamasına sebep olduğu, online eğitimde ise ev ödevi yapma sıklığı Türkçe öğrenme düzeylerini yordamamasına sebep olduğu söylenebilir.

Araştırmada yüz yüze ve online eğitim gören yabancıların Türkçe öğrenme düzeylerini etkileyen faktörlerin incelenmiştir. Araştırma sonucunda elde edilen veriler doğrultusunda, yaptığımız araştırmanın TÖMER ve DİLMER gibi yabancılara Türkçe öğretimi yapan kurum ve kuruluşlar için yol gösterici olduğu söylenebilir. Bu doğrultuda bulguların yabancılara Türkçe öğretimi yapan kurumlar ve uygulayıcılar tarafından dikkate alınması, öğretimin niteliğinin arttırılmasına katkı sağlayabilir. Bunun yanı sıra Yüz yüze veya online eğitim 
yapan öğretim elemanlarının öğretim yöntemi (yüz yüz eğitim-online eğitim) konusunda yeterlilikleri belirlenebilir. Yeterliliği istenilen düzeyde olmayan öğretim elemanları ön eğitim programına alınabilir. Yabancılara Türkçe öğretimi konusunda öğrenci ve öğretmen görüşleri alınarak öğretim yöntem ve tekniklerinin daha verimli bir şekilde uygulanması sağlanabilir. Yüz yüze eğitim ve online eğitimde yabancılara Türkçe öğretiminde ders ilgi çekici bir hale getirilmeli, öğrencilerin ilgi ve motivasyonlarının yüksek olması sağlanmalı ve öğrenciyi merkeze alan, öğrencinin derste aktif olmasını sağlayan öğretim yöntemleri tercih edilmelidir. Öğrencilerin derse katılımları, öğrenme istekleri, devam durumları, dil gelişim hızları ve ödev yapma sıklıkları takip edilmeli ve yetersiz olan öğrencilerin yeterli hale gelmesi için çalışmalar yapılmalıdır. Yüz yüze eğitim ve online eğitim için belirli standartlar oluşturulmalı ve yapılan eğitimin bu standartlara uygun olup olmadığı kontrol edililebilir.

\section{Katkı Oranı Beyanı}

Bu çalışmaya birinci yazar \%60 oranında ikinci yazar \%40 oranında katkı sağlamıştır.

\section{Çatışma Beyanı}

Bu çalışmada herhangi bir potansiyel çıkar çatışması bulunmamaktadır.

\section{Kaynakça}

Al, U. ve Madran, O. (2004). Web tabanlı uzaktan eğitim sistemleri. Bilgi Dünyası 5 (2), 259271.

Aslan, E. ve Coşkun, O. (2016). Yabancılara Türkçe öğretiminde oyun yazılımları ile sözcük öğretimi. Turkisch Studies, 226-227.

Bahşi, A. (2019). Uzaktan ve örgün eğitim öğrencilerinin eğitsel düşünce ve uygulamaları (Yüksek Lisans Tezi). Fırat Üniversitesi, Eğitim Bilimleri Enstitüsü, Elâzı̆̆.

Balta Y. (2014). Türkiye'de çevrimiçi eğitimde ders veren öğretim elemanlarının çevrimiçi ölçme değerlendirme yöntemlerine ilişkin görüşleri (Yüksek Lisans Tezi). Furat Üniversitesi, Elâzı̆̆.

Büyükikiz, K. ve Hasırcı, S. (2012). Yabancı dil olarak Türkçenin öğretiminde sözcük öğretimi üzerine bir değerlendirme. Mustafa Kemal Atatürk Sosyal Bilimler Enstitüsü Dergisi 10 (21), 145-155.

Büyüköztürk, Ş., Çakmak. E., Akgün, Ö., Karadeniz, Ş. ve Demirel, F. (2019). Eğitimde bilimsel araştırma yöntemleri. Ankara: Pegem Akademi.

Cooper, H., Lindsay, J. J., Nye, B. and Greathouse, S. (1998). Relationships among attitudes about homework, amount of homework assigned and completed and student achievent. Journal of Educational Psychology 90 (1), 70-83.

Çallı, İ., Bayram, Y., Karacadağ, M.C. (2002). Türkiye'de uzaktan eğitimin geleceği ve eüniversite. Uluslararası Katılımlı, Açık ve Uzaktan Eğitim Sempozyumu. Anadolu Üniversitesi.

Çataloğlu, E., Erbay, H. ve Kör, H. (2013). Uzaktan ve örgün eğitimin öğrenci başarısı üzerine etkisinin araştırılması. Uluslararası Bilgisayar ve Öğretim Teknolojileri Sempozyumu. Gaziantep Üniversitesi. 
Demir, Y. ve Gözüm, S., (2011). Sağlık eğitiminde yeni yönelimler; Web destekli sağlık eğitimi. Dokuz Eylül Üniversitesi Hemşirelik Yüksekokulu Dergisi, 4(4), 196-203.

Demirel, Ö. (2004). Yabancı dil öğretimi dil pasaportu dil biyografisi dil dosyası. Ankara: Pegem A Yayıncilik.

Demirel, Ö. (2010). Yabancı dil öğretimi. Ankara: Pegem Yayıncılık.

Dündar, Ş. N. (2019). Yabancılara Türkçe öğretiminde dinleme becerisinin bir web uygulaması aracılığılıla geliştirilmesi (Yüksek Lisans Tezi). Gazi Üniversitesi, Eğitim Bilimleri Enstitüsü, Ankara.

Epstein, J. L. (1983). Homework practicez, achievements and behaviors of elementary. ELT Journal, 27(5), 138-143.

Eroğlu F. (2018). Üniversitelerdeki zorunlu ortak derslerin uzaktan ve yüz yüze eğitim uygulamalarının değerlendirilmesi (Yüksek Lisans Tezi). Gazi Üniversitesi, Eğitim Bilimleri Enstitüsü, Ankara.

Eroğlu, F. ve Kalaycı, N. (2020). Üniversitelerdeki zorunlu ortak derslerden Türk dili dersinin uzaktan ve yüz yüze eğitim uygulamalarının karşılaştırılarak değerlendirilmesi. Ana Dili Ĕ̆itimi Dergisi 8(3), 1001-1027.

Göçer, A. (2009). Türkiye'de Türkçeyi yabancı dil olarak öğreten öğretmenlerin uygulamalarına yönelik nitel bir araştırma. Dil Dergisi 145, 28-47.

Gülüşen, F. (2011). Bilgi teknolojilerine dayalı uzaktan eğitim programlarının erişilebilirliklerinin değerlendirilmesi (Yüksek Lisans Tezi). Ankara Üniversitesi, Eğitim Bilimleri Enstitüsü, Ankara.

Höçük, S. (2011) Ankara Üniversitesi uzaktan eğitim programına katılan öğrencilerin akademik başarılarını etkileyen faktörler (Yüksek Lisans Tezi). Ankara Üniversitesi, Ankara.

İşman, A. (1998). Uzaktan Eğitim: Genel tanımı Türkiye'deki gelişimi ve proje değerlendirmeleri. Ankara: Değişim Yayınları.

Karakuş, İ. (2006): Atatürk dönemi eğitim sisteminde Türkçe öğretimi. Ankara: Türk Dil Kurumu Yayınları.

Karataş, S. (2003). Yüz yüze ve uzaktan eğitimde öğrenme deneyimlerinin eşitliği. Ĕ̆itim Bilimleri ve Uygulama, 2(3), 103.

Kaya, M. (2012). Uzaktan eğitimde öğrenenlerin yabancı dil öğreniminde özerk öğrenme becerileri: Uzaktan IÖLP Örneği (Yüksek Lisans Tezi). Anadolu Üniversitesi, Sosyal Bilimler Fakültesi, Eskişehir.

Khomenïuk, A. (2020). Ukrayna' da yabancı dil olarak Türkçe öğretimi ve karşılaşılan sorunlar üzerine bir inceleme. Uluslararası Yabancı Dil Olarak Türkçe Öğretimi Dergisi. 3(1): 5-20.

Köksal, D. ve Varışoğlu, B. (2012). Yabancı dil öğretiminde yaklaşım yöntem ve teknikler.: A. Kılınç ve A. Şahin (Ed.), Yabancı Dil Olarak Türkçe Öğretimi. Ankara: Pegem.

Kör, H. (2013). Uzaktan eğitim ve örgün eğitimin çok yönlü - çapraz karşılaştırılması: Kırıkkale Üniversitesi ve Hitit Üniversitesi Örneği (Yüksek Lisans Tezi). Kırıkkale Üniversitesi, Fen Bilimleri Enstitüsü, Kırıkkale. 
Kurt, T. (2021). Ortaokul öğrencilerinin yabancı dil öğrenimine yönelik kaygı, öz yeterlilik ve başarı durumlarının incelenmesi (Yüksek Lisans Tezi). Kırşehir Ahi Evran Üniversitesi, Sosyal Bilimler Fakültesi, Kırşehir.

Küçükahmet, L. (2002) Öğretimde planlama ve değerlendirme. Ankara: Nobel Yayınevi.

Memiş, M. R., \& Erdem, M. D. (2013). Yabancı dil öğretiminde kullanılan yöntemler, kullanım özellikleri ve eleştiriler. Turkish Studies, 8(9), 297-319.

O'Neil, Carol A., Fisher, Cheryl A. \& Newbold, S. K. (2009). Developing online learning environments in nursing education. New York: Springer Publishing Company. 83-97.

Horton, E. (2000). Desingning web based training. John Willey.

Snow, C. E., Barnes, W. S., Jean, C., Goodman, I. F., Hemphill, L. (199). Unfulfilled expectations: Home and scholl influebces on literacy. Harvard Universy Press, 1991.

Spooner, F., Jordan, L. ve Algozzine, B. (1999). Student Raitings of İnstruction in Distance Learning and On-Campus Classes. Journal of Educational Research, 92, 132-141.

Stack, S. (2015). Learning Outcomes in an Online vs Traditional Course. International Journal for the Scholarship of Teaching and Learning, 9(1).

Summers, J., Waigandt, A. and Whittaker, T. A. (2005). A Comparison of Student Achievement Ans Satisfaction in an Online Versus a Traditional Face-to-Face Statistics Class. Innovative Higher Education, 29(3): 233-250.

Şenyïğit, Y. ve Okur, A. (2019). Yabancllara Türkçe öğretiminde konuşma becerisi ve telaffuz eğitimi. Mehmet Akif Ersoy Üniversitesi Eğitim Fakültesi Dergisi, (52), 519-549.

TeknologWeb (Nisan, 2021). Mobil öğrenme nedir? https://www.teknologweb.com/mobilogrenme-nedir adresinden edinilmiştir.

Tosun, N. (2007). Uzaktan eğitim ve Trakya Üniversitesi uzaktan eğitim projesi. VII. International Educational Techology Conference, Kuzey Kıbris.

TÖMER. (2011). Yönetmelik. Erişim: 15 Kasım 2020. http://tomer.ankara.edu.tr/mevzuat/ adresinden edinilmiştir.

TÖMER. (2020a). Genel Bilgi. Erişim: 25 Ekim 2020. www.tomer.ankara.edu.tr/genelbilgi/ adresinden edinilmiştir.

TÖMER. (2020b). Koşullar. Erişim: 25 Ekim 2020. www.tomer.ankara.edu.tr/kosullar/ adresinden edinilmiştir.

Türk Dil Kurumu. (2020). Türkçe Sözlük. Ankara: TDK

Yazıcı, S. (2004). E- Öğrenme: İnsan kaynakları eğitiminde stratejik dönüşüm. İstanbul: Alfa Basım.

Yeniad, M. (2006). Uzaktan eğitimde kullanılmak üzere web tabanlı bir portal yazılımı geliştirme (Yüksek Lisans Tezi). Çukurova Üniversitesi, Sosyal Bilimler Enstitüsü, Adana. 